\title{
ROLE OF LEARNING ORGANIZATION IN BUILDING CONSUMER CONFIDENCE
}

\section{Małgorzata Adamska, Martina Minárová}

\section{Introduction}

Present century is the century in which the nature of business is changing. Management has to handle new methods. According to Kotler and Armstrong [10], there are two types of businesses: those that change and those that disappear. One of the strategic objectives of every modern organization is to achieve a competitive advantage in the sector in which it operates. Markets, customers, competitors and technology are changing. If a company wants to be successful, it must change, too. Otherwise, its key competences can easily become problems which would lead to a business failure. Applying the concept of a "learning organization" as a method of management and education is the way how to prevent mistakes and create a strategic business advantage. To achieve a desired competitive position is not possible without creating a relationship based on trust. Customer capital plays a key role in building a competitive advantage, within the context of which it is important to build consumer confidence in different areas of the organization.

The main objective of our paper is to emphasize the importance of the concept of a learning organization in the field of building and managing consumer confidence in a life cycle, taking various phases of customer's activity into account. This paper consists of three basic parts. The first part discusses a general concept of intellectual capital and market capital of an organization using the standard method of literature review and critical analysis of the literature sources. The second part describes customer capital which results from various phases of the cycle of customer's activity in the market. The third part presents partial results of the research of project VEGA - The Learning Organization. We identified application of the principles of a learning organization in SMEs in Slovakia which emphasizes the importance of continuous improving satisfaction of existing and future customers.

\section{Market Capital of an Organization in the Intellectual Capital Structure}

Key elements of intellectual capital have been developed from physical capital through the organizational capital to the key human capital nowadays. Among the criteria monitored in the development of knowledge-based companies are the following [15]:

- economic and institutional system that provides incentives for the efficient use of existing and new knowledge and prosperous business,

- educated and skilled population that can create, share and use knowledge,

- dynamic information infrastructure that can enable effective communication and information processing,

- efficient innovation system of businesses, research centers, universities, consultants and other organizations to enable participation in the growing amount of global knowledge and ability to adapt it to local needs, as well as ability to create new technologies.

The abundance of literature in this particular subject provides many different definitions of the term Intellectual Capital [3], [22], which hasn't been accurately defined for a long time. Recently, experts specializing in different fields have cooperated together which resulted in creation of many different definitions of the Intellectual Capital. The approach to this 
particular issue has already been discussed, and is expected to be talked about in the future, from many different points of view arising from the complexity of the intellectual capital of an organization and its presence in all the areas it operates. In the context of marketing activity intellectual capital is essential in creating an image of an organization by implementing activities in areas such as building relationships with customer capital and making a customer aware of a market brand and the producer by effective consumer confidence management. Marketing activities of modern organizations must be fully focused on the customer and must ensure the fulfillment of the expectations of each market segment. This requires a huge intellectual effort associated with proper and effective use of market knowledge, which is the most important resource in the process of building company's leading competitiveness [18].

Amongst the different concepts of intellectual capital (Tab. 1) in the components proposed, there is customer, relationships, or specifically, customer capital, as an element essential in the process of creating the market value of an organization.

\section{Tab. 1: Overview of the components of intellectual capital by various authors}

\begin{tabular}{l|l|l} 
Authors & Intellectual capital context & Suggested components \\
\hline Kaplan, Norton & Balanced Scorecards & $\begin{array}{l}\text { customers } \\
\text { the internal structure of an enterprise } \\
\text { processes: learning and innovation } \\
\text { finance }\end{array}$ \\
\hline $\begin{array}{l}\text { Petrash, Edvinsson, } \\
\text { Onge, Armstrong } \\
\text { Bukowitz, Williams }\end{array}$ & Value Platform & $\begin{array}{l}\text { human capital } \\
\text { customer capital (relationships) } \\
\text { organizational capital (structural) }\end{array}$ \\
\hline Haanes, Lowendahl & Intangible resources classification & $\begin{array}{l}\text { competence } \\
\text { mutual relations }\end{array}$ \\
\hline Brooking & $\begin{array}{l}\text { Identifying components of } \\
\text { intellectual capital }\end{array}$ & $\begin{array}{l}\text { market assets } \\
\text { assets related to the human factor } \\
\text { infrastructure assets } \\
\text { market value }\end{array}$ \\
\hline Stewart & $\begin{array}{l}\text { Identifying components of } \\
\text { intellectual capital }\end{array}$ & $\begin{array}{l}\text { human capital } \\
\text { structural capital } \\
\text { capital associated with customers }\end{array}$ \\
\hline Bratnicki, Strużyna & A value tree of an enterprise & $\begin{array}{l}\text { social capital } \\
\text { human capital } \\
\text { organizational capital }\end{array}$ \\
\hline Fitz-enz & Intellectual capital elements & $\begin{array}{l}\text { human capital } \\
\text { processes and culture } \\
\text { Intellectual Property } \\
\text { relationships }\end{array}$ \\
\hline
\end{tabular}

Intellectual capital has long been present in the practice of management in each area of an organisation, including, amongst others, an effective market capital management due to finding solutions which ensure proper relations for an organisation to operate in a specific, complex market environment.
The factor creating the market capital structure of an organisation, being customer relationships, the relationship with vendors, market competence, other market relations and public relations, is its complex marketing activity.

The structure of the capital market can be divided into three basic groups: Customers, 
Competitors and Contractors [1]. All the elements of market capital have an impact on an individual organisation and the same time on each other. The concept of market capital draws from the Model 5 competitive forces within the market sector by Michael Porter [21]. Alongside the threat of new entry and substitute products, as well as services, being external factors which have an impact on the competitiveness of enterprises, he identified: bargaining power of buyers, bargaining power of suppliers, and rivalry among existing firms.

The analysis of market capital of an organisation, apart from a meticulous and detailed description of its current market position, should be a description of the external environment in which it operates. In particular, it is relevant in the context of creating a strategy for the future impact on the customer capital activity at different stages of its life cycle.

By defining the components of intellectual capital according to OECD studies, we conclude that while financial capital shows the history and results achieved in the past, process and market capital are components based on current operations, capital recovery and development. These components determine how the company is prepared for the future and how the human capital represents skills, professional knowledge and willingness to learn, and at the same time how it allows people to create value in all other components of the intellectual capital. There are also easier ways to divide the intellectual capital [19] and that is division into human capital (human values such as intellect, experience, skills, creativity, procedures, etc.), structural capital (businessowned tools, such as systems, intangible property, processes, databases, values, culture, etc.) and relational capital (external relationships with customers, suppliers, business partners, distribution networks, and regulation of trade).

\section{Customer Capital - in the Context of Life Cycle Phases}

Market, customer needs, and customer life cycle are the categories that are interdependent. Marketing represents the management process, whose dominant criterion is market. Market represents customer needs and individual customers have their own needs. This management process is very difficult, because it is under pressure of globalization and internationalization [20]. Entrepreneurs have been asking themselves a question: Who is our customer? The information they need is who, out of the customers, is the most profitable for the enterprise. The organization must know the resources required to meet customer requirements and achieve its expectations [14].

The purpose of marketing activities is to gain knowledge and understanding of what the client wants and then provide it while achieving profit for the enterprise [11].

Consumer buying behaviour may be defined as "the environment and decision process affecting individuals and groups when evaluating, acquiring, using or disposing of goods, services or ideas" [22].

The relationship developed with customers is of a great importance to an enterprise in terms of achieving the enterprise's main goals, such as increased productivity, market share, and a range of influences.

Hallberg, in his publication 'All Consumers Are Not Created Equal' formulated the socalled customer's life cycle with a company, which illustrates what impact on the enterprise's profit the life cycle phases have in the relationship between a customer and an enterprise. For this purpose, three groups of customers were distinguished accordingly, related to the periods of cooperation - from the start to the end [6], [8]:

- new customers - who benefit from the company's offer for the first time,

- returning customers - customers who decide to continue shopping after the first contact with the company, and become multiple buyers,

- lost customers - who stopped buying products of the given company.

However, this division does not take into account the group of potential customers, therefore the proposal was made that the result of conducting an effective analysis and of customer capital characteristics, would be the following three main groups of customers in relation to time and lifecycle of customer: past, present and future [7].

Past customers - the first group of customers was of value to an enterprise in the past. The customers exerted an influence on the enterprises' activity by providing knowledge about their needs and their expectations. The 
fact that customers start desisting from the demand activity might mean that their expectations are not met which can result in losing customers. An important reason for that may be a lack of loyalty and trust in the brand, which indicates that a customer goes by the argument of low prices, very often at random. It is therefore worth knowing which factors prompted the customer to leave, which could help in drawing conclusions for the future and in developing an effective customer orientation. Passivity of a customer might also attest to the shift of goods offered by an enterprise towards the sphere of unnoticeable goods.

Current customers constitute the second group. It is a group which represents an active, in demand, current customer database, determining the present activity of an organization. Current customers, despite their stability, still expect the company's interest in their needs. No matter what the company's profile and the industry are, customers require good service and direct contact.

In the case of fast moving goods, which are purchased 'off-the-shelf' and desired by a customer in a variety of distribution channels, the maintenance of relationships with customers depends on the offered product (mix marketing elements - product and its packaging, obtained quality and usability, price and purchasing convenience), but above all by the image created. Customers make specific purchasing choices by accepting an offer and by identifying with the enterprise's image. The main methods of exerting an influence and communicating with current customers are active promotion tools and extensive market research, designed to gather information from the market to help in adjusting the offer to customers' needs.

Future customers are the market participants the companies are interested in because anyone who is not the company's customer is the customer of the competitors. The process of obtaining customers is predominantly carried out by the same means of media (promotion) as it is used in activities associated with maintaining the existing customers. However, it does not only apply to advertising in the media, and the process of customer trust building should begin long before the start of an active customer life cycle.

Changes in the business environment require a more flexible organization which is able to respond promptly to the market situation. People are playing the key role in the continuous adaptation of business. Traditional strategic planning processes are too slow and therefore the competence and responsibility for decision are transmitted to people who must be able to proactively detect potential opportunities in new situations.

Human resources are considered as the key source for business. On the other hand, the literature indicates that human resources are utilized in business only up to forty percent. This paradox is caused by insufficient use of manpower, skills and abilities of workers, their improper integration into the workforce, insufficient use of their knowledge in management of the organization (lack of feedback), and other factors. Within service businesses, where the worker is in direct contact with the customer, his lack of acceptance is considered as a strategic mistake. For businesses it is very important to build trust and customer loyalty. By applying the principles of a learning organization, businesses are directed towards continuous learning, acquisition and sharing of new knowledge that can be used for building confidence in individual stages of the customer life cycle.

\section{Learning Organization in SMEs in Slovakia and Building Customer's Confidence}

Knowledge Management provides organizations with a lot of changes [5]. According to Alavi and Leidner [2] the most significant changes include changes in communication (acceleration, improving of communication, and ensuring employee participation in communication), labor efficiency (reducing the time of creating the innovation, and increased productivity), finance (increase in turnover and cost reduction), marketing (expansion and improvement of customer service, strong customer orientation, and introduction of a targeted marketing).

Knowledge management is the response to the emergence of new ways of creating wealth based on information and knowledge. Its implementation ensures that the organizations maintain their position in the current turbulent environment. One of the ways to ensure management and sharing of knowledge in the organization is to create a learning organization [13]. 
The ability of individuals to use the acquired knowledge in their daily work enables flexible and quick response to emerging situations as well as dealing with them right, with regard to the efficiency of the company. What really matters is good communication, which means being perceptive to the messages that other people (e.g. customers) are conveying through their verbal and non-verbal communication cues. This is especially visible in the field of business, where the differences in values and assumptions are projected in the ways people react in many common situations [4].

To create the concept of a learning organization, it is necessary that managers learn from experience. Preferred ways of learning must be recognized and support of some features such as openness, creativity, systems thinking, helpfulness, etc., is inevitable. Learning organization must have a system, and at the same time procedures and processes that are constantly developing the capabilities of individuals to achieve objectives. Based on comparison and synthesis of research conducted in Slovakia [11], [15] and in Bohemia [17], [23], [24], knowledge management is not an active part of the management of organizations. Also businesses which applied elements of knowledge management have done it unsystematically and often subliminally.

Knowledge management is considered only for education or the use of information technologies when working with information. Barriers to creation and transfer of knowledge are especially afraid of the knowledge abuse, fear of incomprehension of knowledge, ignorance that the given knowledge also needs someone else, and lack of mutual confidence. Similar findings were obtained from the pilot survey, which was conducted as a preliminary activity of the project VEGA at Faculty of Economics, Matej Bel University. The survey was conducted by questionnaire on a sample of 263 respondents. The studied sample of organization we have compiled a random sampling method, and it consisted mainly of small and medium-sized enterprises (85\%), non-profit organizations $(13 \%)$ and professionals $(2 \%)$ operating in the territory of central Slovakia (industrial enterprises $58 \%$ and organizations in services sector 29\%). The object of our research was questions about the nature and importance of learning organization, as well as the issue of the conditions and factors influencing its adoption and use. The partial objective was to understand how a learning organization is perceived by managers in Slovak business and importance of this perception in building (creating) costumer confidence of current and potential customers. Prevailing majority of respondents (82\%) defined the content and nature of knowledge management correctly, and $78 \%$ confirmed the necessity of its use in their organization. Among factors that support successful learning organization implementation, $63 \%$ respondents determined the appropriate corporate culture, $31 \%$ chose continuing education and learning, and $4 \%$ emphasized the condition of creating knowledge-managerial functions (e.g. the Chief Knowledge Officer). These findings establish appropriate underlying assumptions to define the objectives of the research project VEGA $1 / 0638 / 08$ - Learning Organization. The research was conducted in 2010 at the Faculty of Economics, Matej Bel University in Banska Bystrica. 700 online questionnaires were distributed among chosen small and medium businesses in Slovakia, out of which 580 returned.

For research purposes, we used 547 correctly completed questionnaires. The largest number was represented by organizations operating in the machinery industry $(17.55 \%)$, then services (14.99\%) and finally trade $(14.44 \%)$. The questions were answered by means of questionnaire, by manager's at all hierarchical levels. The lowest-level managers were represented by the group of $51 \%$ of respondents, the managers at central level were represented $34 \%$ and finally, $15 \%$ were the group of top managers. The aim of the research was to determine to what extent the principles of a learning organization are applied in the selected SMEs. We examined the areas in which enterprises are strong in applying the principles of a learning organization, and, vice versa, where they have weaknesses. Respondents answered by rating scale from 1 to 5 while 1 stood for 'never' (or least accurately) and 5 for always (most precise). Research results confirmed that Slovak companies, even if not learning organizations, broadly apply principles specific to this concept. Within this paper we want to point out the aspect of trust from the point of view of importance for building the principles of a learning organization, as well 
as its direct relation to building customer trust. We have based our research on a statement that there is a direct link in between how the company is perceived by the employees and by customers. When managers lose trust of their employees, the employees do not feel good and consequently, this negative energy brings subliminal messages which the employees (mainly when in direct contact with the customer) spread further towards the customers.

Our opinion is that most organizations place the emphasis on the customer and hold the motto "our customer is our king." In this area we achieve the highest value of 4.18 points, fig. 1 . We should emphasize that although the consumer is understood as the most important market participant according to the motto, it will not show into everyday business activities. Musová [19] argues that this motto carries signs of a proclamation. An important condition for developing a learning organization is the fact that employees have no problem in passing their experience between each other and respecting each other, which was reflected in a number of analyzed organizations. Value of 3.99 point, convinced us that not only the employees themselves create a learning organization, but in our businesses it is also leadership that encourages company's employees to be asked to expand both its knowledge and skills. Management underestimates rewarding their employees for their growth and continuous improvement, which we managed to confirm (3.25 points). We found out that the staff in the analyzed organizations does not have difficulty obtaining relevant information and participating in the learning process. The weak point is the system of evaluation and measurement of learning outcomes in relation to resources spent (3.06 points). One of the factors when building an organizational culture of a company, is confidence in employees' skills, which greatly influences sharing of the organization's knowledge [16]. The answer to the questions concerning trust in employees' skills was evaluated very positively. Managers lead their employes to independence and trust them in new challenges which they face (3.71).

\section{Fig. 1: Research results}

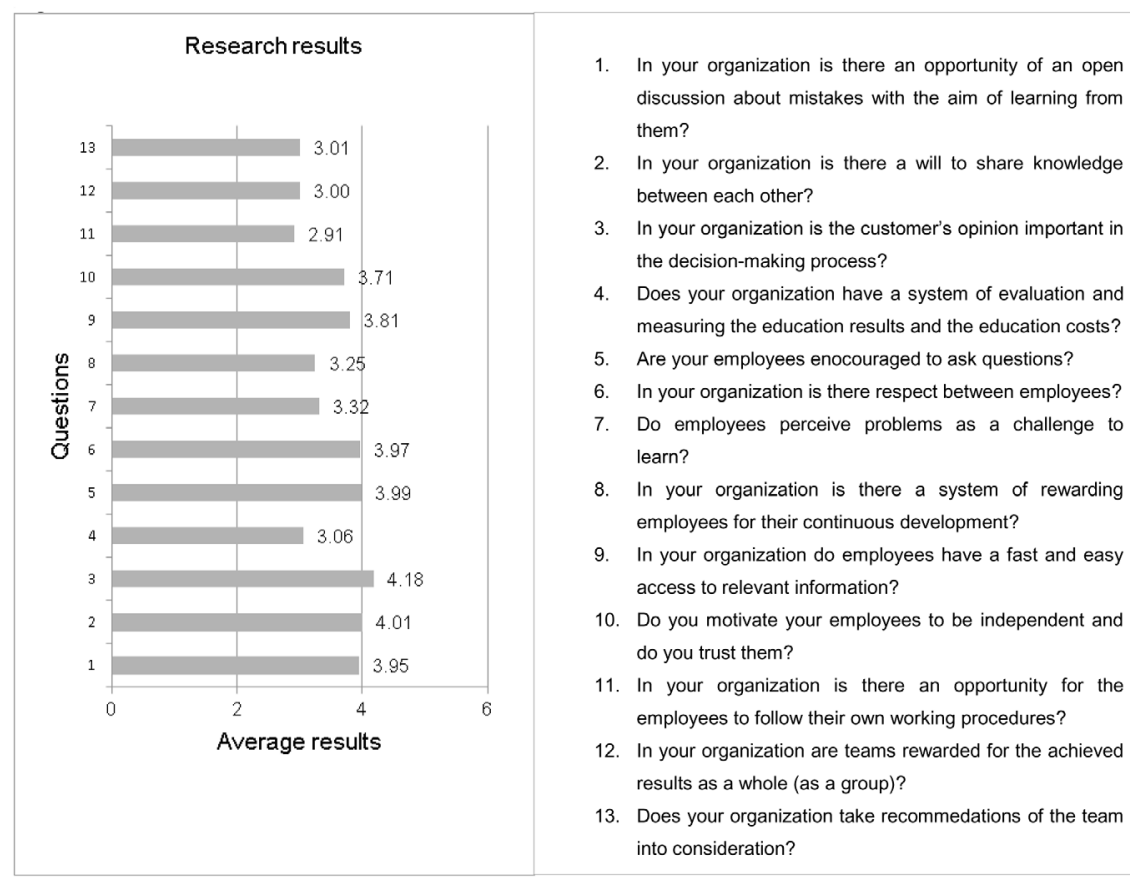


Within this research we searched for a specific way of knowledge exchange, while the following categories were detemined as the options: knowledge exchange on basis of orders of management, principles of trust, working relations, and knowledge exchange on basis of personal and friendly relationships with one's colleagues. As it can be seen in Fig. 2, only in $9 \%$ of the analyzed companies there exists knowledge exchange with colleagues, as based on personal and friendly relationships. The fact that knowledge of the company is exchanged and spread (disseminated) on basis of the working relationships (hierarchy), was confirmed by $41 \%$ of our respondents. From the point of view of evaluating the corporate culture it was very interesting for us to see the percentage of companies in which knowledge is exchanged on basis of already built confidence between the employees and the management. This option was only chosen by $19 \%$ of respondents. The opposite to this is knowledge exchange based on orders from the management.This situation can be noted mainly in companies where the activities are performed with the use of an individual approach, with the absence of team cooperation and creativity, as well as throught preference of the already established working procedures and available knowledge. In our sample we have noted $31 \%$ of companies where exchange and dissemination of knowledge is partly based on orders from the management.

\section{Fig. 2: Way of knowledge exchange in SMEs}

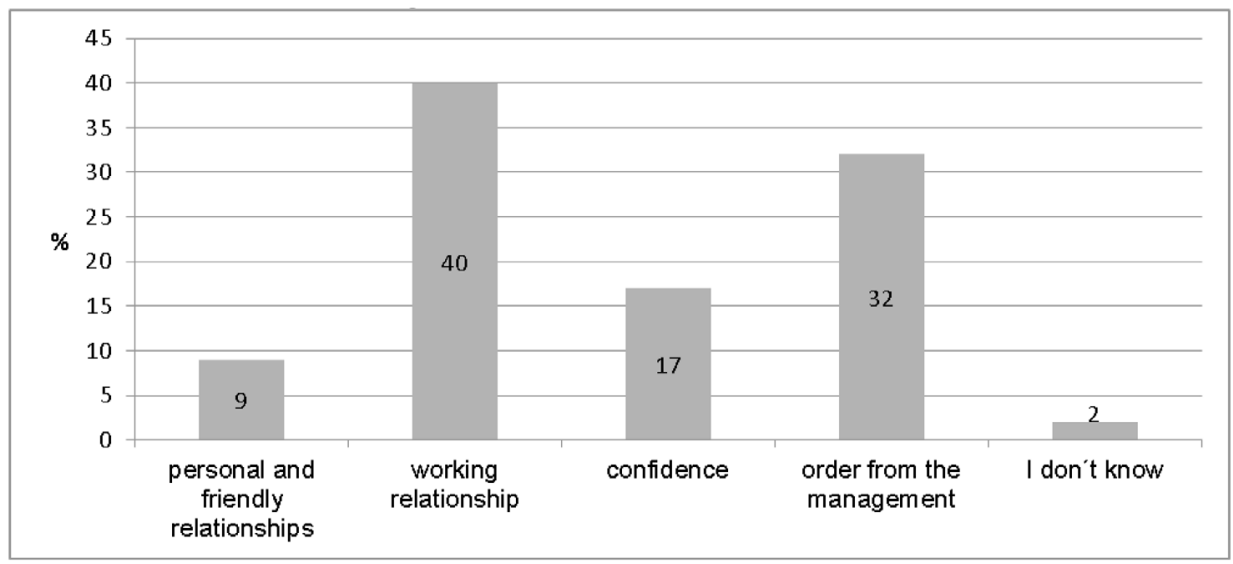

Source: own research

When finding out the importance of knowledge exchange between the employees and building customer trust we asked respondents a question how much they agree with a given statement. As it can be seen from Fig. 3, majority of respondents (57\%) do not see a direct connection between how the company is perceived by the employees and how it is perceived by the customers. Only $17 \%$ (93 respondnents) agreed with the given statement.
On bases of the above stated we can say that the respondents of the analyzed companies do not consider relationship between knowledge exchange and building customer confidence important (Fig. 3). Therefore, it is important to appeal to managers and point out the reasons or building a learning organization in companies, because when there is an open corporate culture and the knowledge exchange is based on trust, customer needs are detected and and understood in 


\section{Fig. 3: Importance of knowledge exchange and building customer trust}

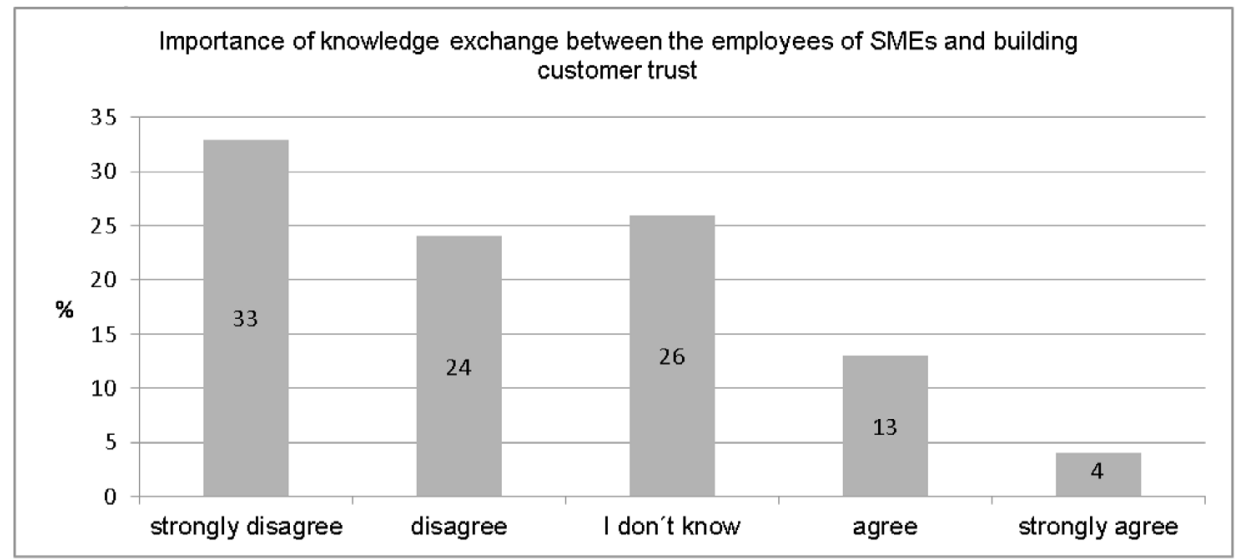

Source: own research

each phase of the life cycle. Customer capital is understood as organization's knowledge about customer needs, their preferences and qualitative values. Customer capital in important mainly because it helps create a relationship of the organization towards its customers and development of this relationship. On basis of mutual trust the current emloyees become loyal, not past cutomers. Their positive experience is shared with others, which helps the company to address potential customers.

For organization that wants to become a learning organization, it is necessary to realize that this is a complex and lengthy process that requires a lot of effort; and the objective is to continuously increase the satisfaction of existing and future customers [9], [12].

\section{Conclusions}

Creation, development, use and evaluation knowledge is crucial for the organization, for ensuring its further development, as well as in terms of gaining and maintaining the competitive advantage. In the last years may be seen increasing importance of intellectual capital and its enforcement as the most important form of capital. Other forms of capital (technology, money, land) are dependent on the knowledge capital.
Knowledge management deals with human resource management and therefore is likely to be a long-term and effective business tool.

Modern organizations need to develop awareness of the need for a comprehensive customer capital management of organizations in various stages of the life cycle. The level of confidence that has been developed with customers will determine the predicted dynamics, the future effects of an organization, both economic and social. A well-managed customer capital supports the process of achieving the objectives (strategic and operational) of active organizations, satisfaction of customers, and it also supports the launch of new or modified products due to knowledge of each market segment. So as knowledge could flow through the organization without any problems, employees must trust each other and know that they will also be provided knowledge by their colleagues. This way of knowledge exchange is considered most important when evaluating the corporate culture which is one of the main prerequisites of building a learning organization. Only in such case they will be willing to share the knowledge. It is the employees in learning organizations who create the highest value for the external customers. It is essential that management reward and evaluate employees 
who share their knowledge with others. At the same time it is necessary for the management to support the employees in asking questions and thus provide better access to information which is relevant, to permanently increase satisfaction and trust of the existing and future customers.

Intensive marketing activities focuses on achieving a competitive advantage by earned confidence in the brand and the product manufacturer, which will bring the expected results to the organization. Customer capital activity will thus be reflected in the market position of the organization.

\section{References}

[1] ADAMSKA, M. Customer capital of modern business and its impact on efficiency. In Mezinárodní Masarykova konference pro doktorandy a mladé vědecké pracovníky 2011. Hradec Králové: Magnanimitas, 2011. p. 906-914. ISBN 978-80-904877-7-2.

[2] ALAVI, M., LEIDNER, D. Review of knowledge management and knowledge management systems: Conceptual foundations and research issues. MIS Quarterly. 2001, Vol. 25, Iss. 1, pp. 107-136. ISSN 2162-9730.

[3] ALTKORN, J., KRAMER, T. Leksykon marketingu. Warszawa: Polskie Wydawnictwo Ekonomiczne, 1998. 275 p. ISBN 83-208-1087-6.

[4] BENČIKOVÁ, D. What is the $C Q$ and how to benefit from it? Management of Cultural Diversity: What Are the Stakes in Europe? Under direction of Thierry Côme and L'udmila Mešková. Bruxelles: Bruylant Collection, 2011. p. 65-75.

[5] BUREŠ, V. Konceptuální perspektiva znalostního managementu. E+M Ekonomie a Management. 2009, Vol. 12, Iss. 2, pp. 84-96. ISSN 1212-3609.

[6] CICHOSZ, M. Lojalność klienta a logistyka firm usługowych. Warszawa: Szkoła Główna Handlowa w Warszawie, 2010,15 p. ISBN 978-83-7378509-0.

[7] DĚDKOVÁ, J., LOŠTÁKOVÁ, H. Současný stav identifikace zákazníků ve firmách působících na spotřebním trhu při uplatňování "CRM“. E+M Ekonomie a Management. 2007, Vol. 10, Iss. 4. pp. 92-99. ISSN 1212-3609.

[8] HALLBERG, G. All Customers Are Not Created Equal. Toronto: Wiley \& Sons, 1995. 309 p. ISBN 0-471-12004-9.
[9] HOMMEROVÁ, D. Výzkum zavádění CRM $\checkmark$ podnikové praxi. E+M Ekonomie a Management. 2009, Vol. 12, Iss. 1, pp. 108-122. ISSN 1212-3609. [10] KOTLER, P., ARMSTRONG, G. Marketing. Praha: Grada Publishing, 2004. 856 s. ISBN 80-247-0513-3.

[11] KOTLER, P. Marketing. Poznań: Dom wydawniczy Rebis, 2005. pp. 57-61. ISBN 83-7301-532-9. [12] KUBINA, M., LENDEL, V. Hexagonal Stellar Model of CRM - Key Elements Influencing the CRM Building. E+M Ekonomie a Management. 2012, Vol. 15, Iss. 1, pp. 57-72. ISSN 1212-3609. [13] LIBERKO, I., MALÁK, M. Implementácia a využitie znalostného manažmentu pri zlepšovaní procesov $v$ marketingovo orientovanej firme. In Zborník z medzinárodných vedeckých dní. Nitra: SAU, Fakulta ekonomiky amanažmentu, 2006. pp. 879-883. ISBN 80-879640-01-0.

[14] MALÁ, D. Prepojenie modelu výnimočnosti EFQM a vybraných manažérskych modelov. KVALITA. 2008, Vol. 15, Iss. 2, pp. 18-23. ISSN 1335-9231.

[15] MALHOTRA, Y. Measuring Knowledge Assets of a Nation: Knowledge Systems for Development, State of Research 2003-2004. Syracuse (NY), 2003. 48 p. Syracuse University \& United Nations. Available also from: http://www.kmnetwork.com/ KnowledgeManagementMeasurementResearch.pdf. [16] MESÁROŠ, P. Znalostná kultúra v podniku predpoklad implementácie manažmentu znalostí. Manažment $v$ teórii a praxi. 2005, Vol. 1, Iss. 3, pp. 55-60. ISSN 1336-7137.

[17] MLÁDKOVÁ, I. Knowledge Management in Companies in Czech Republic. Ekonomika a manažment podniku. 2004, Vol. 2, Iss. 1, pp. 19-27. ISSN 1336-4103.

[18] MROZIEWSKI, M. Kapitaǵ intelektualny wspóǵczesnego przedsiębiorstwa. Koncepcje, metody wartoéciowania $i$ warunki jego rozwoju. Warszawa: Wydawnictwo Difin, 2008. 29 p. ISBN 978-83-7251-857-6.

[19] MUSOVÁ, Z. Spoločenská zodpovednost' v marketingovej praxi podnikov. Banská Bystrica: Univerzita Mateja Bela, Ekonomická fakulta v Banskej Bystrici, 2013. 228 p. ISBN 978-80-557-0516-3.

[20] POLIAČIKOVÁ, E. Manažment k'účových zákazníkov. 1. vyd. Bratislava: lura Edition, 2012. 101 p. ISBN 978-80-8078-451-5.

[21] PORTER, M.E. The five competitive forces that shape strategy. Harvard Business Review. 
2008, Vol. 86, No. 1. [cit. 2013-03-19]. Available from: http://hbr.org/product/the-five-competitiveforces-that-shape-strategy/an/R0801E-PDFENG? referral=00269. ISSN 0017-8012.

[22] SARGEANT, A., WEST, D.C. Direct and Interactive Marketing. 1st ed. Oxford University Press, 2001. 484 p. ISBN 978-0-19-878253-7.

[23] TRUNEČEK, J. Management znalostí. Praha: C. H. Beck, 2004. 131 p. ISBN 80-7179-884-3.

[24] VYMETAL, J., DIAČIKOVÁ, A., VÁCHOVÁ, M. Informační a znalostní management $v$ praxi. Praha: LexisNexis CZ, 2005. ISBN 80-86920-01-1.
Ing. Małgorzata Adamska, Ph.D.

Opole University of Technology

Faculty of Economics and Management Department of Economics and Regional

Research m.adamska@po.opole.pl

Ing. Martina Minárová, Ph.D. Matej Bel University in Banska Bystrica Faculty of Economics Department of Corporate Economis and Management martina.minarova@umb.sk 


\title{
Abstract
}

\section{ROLE OF LEARNING ORGANIZATION IN BUILDING CONSUMER CONFIDENCE}

\author{
Małgorzata Adamska, Martina Minárová
}

The proof of intellectual capital excellence is the current business practice that requires attention and focus on this kind of capital. The intellectual capital of an organization is the sum total of its human capital, structural capital and relational capital. These assets form a source of competitive advantage and distinguish the performance of one organization from the other. Having control on intellectual capital enables effective knowledge sharing, on the one hand and improvement of customer relationship on the other. The increase of knowledge and its relationship with the learning process is a very important for organization. It is widely accepted that organization which invest in the creation of new knowledge and increasing the intellectual capital through research and development activities or tend to do better than those that ride on the coat of knowledge created by others. The results of our research extend the understanding of the role of organizational learning in creating intellectual capital and building sustainable advantages for organization, where different concept of the customer confidence management in various stages of the customer capital life cycle may bring different implications for valuation of intellectual capital. This paper presents and describes customer capital of an organization as an element of market capital in the structure of the intellectual capital of modern organizations. For businesses it is very important to build confidence and customer loyalty. To be able to build on it, they have to gain the confidence of customer. By applying the principles of a learning organization tend businesses to continuous learning, acquisition and sharing of new knowledge that can be used for building confidence in individual stages of the life cycle of the customer.

Key Words: Customer trust, customer capital, market capital, intellectual capita, learning organization.

JEL Classification: M31, M14.

DOI: 10.15240/tul/001/2014-1-005 